\title{
Research on the Development Path of Beijing Community Participation in Tourism Town
}

\author{
Shunmei Yu \\ School of economics and management, Beijing Jiaotong University, Beijing 100000, China.
}

Keywords: Tourism town; Community participation; Beijing; Development path.

Abstract. The purpose of this study was to analyze the current situation of community development in Beijing's tourism towns and provide reference for the sustainable development and community construction of tourism towns in Beijing. The article uses field trips and data collection methods to measure the participation of 14 tourism towns in Beijing. The results we obtained demonstrate that the development of tourism towns in Beijing lack of active participation; low level of participation, simple participation; lack of organizational leadership and no guarantee mechanism. Our results suggest establishing a legal system; ensure the participation of community residents; pay attention to the role of non-governmental organizations as a bridge. However, due to the different stages of development of tourism towns in various regions, the recommendations in the article do not apply to the development of all tourism towns.

\section{Introduction}

Tourism towns are natural and human resources with unique or higher tastes. Tourism, leisure or business tourism activities are frequent. The tourism economy is absolutely dominant or dominant in the local economy. The tourism industry is a small town with obvious economic, social and cultural development [1]. In the process of accelerating urbanization in China and moving rapidly towards the post-industrial era, tourism towns have shown vigorous development momentum and great development potential. Guofa No. 31 "Several Opinions of the State Council on Promoting the Reform and Development of Tourism" clearly proposes to promote the organic integration of rural tourism and new urbanization, rationally use ethnic villages and ancient villages, and develop tourism with historical memory, regional characteristics and national characteristics. In the town, build a group of famous scenic spots and famous towns [2]. The conflicts erupted in the development of tourism villages and towns in recent years show that the social effects of community participation and tourism are important factors that cannot be ignored. Only by increasing community participation can the sustainable development of tourism town be realized [3]. The National Development and Reform Commission, the Ministry of Land Resources, the Ministry of Environmental Protection and the Ministry of Housing and Urban-Rural Development issued a number of "Opinions on Standardizing the Promotion of Characteristic town and Characteristic Small Town", which clearly pointed out that it is necessary to promote diversified entities to work together in the same direction, build and share, and improve the people. A sense of gain. Retain the living space of the original residents and avoid the migration of the original residents as a whole during the development of tourism towns.

\section{Development Status of Tourism Towns in Beijing}

\subsection{Analysis of tourism resources of small towns in Beijing.}

There are many towns around Beijing and rich in tourism resources. A total of 14 towns have been selected for the list of famous villages and towns with national characteristics (As shown in Table 1). It has rich cultural resources, among which the Great Wall culture, historical sites and red tourism culture are the most prominent. More towns are the location of the Great Wall. On the basis of the Great Wall culture, the town has intensively explored characteristic tourism resources, implanted in planting, aquaculture and other industries, vigorously developed tourism, and achieved good returns and solved the town's infrastructure. The people's livelihood issues such as construction and employment of residents will serve as a model for the development of Tourism Town across the country. 
Table 1 The tourism resources of Beijing characteristic landscape tourism town

\begin{tabular}{|c|c|c|}
\hline Name & Tourism resource characteristics & Culture \\
\hline $\begin{array}{l}\text { Zhaitang Town, } \\
\text { Mentougou District }\end{array}$ & $\begin{array}{l}\text { Ming and Qing Dwelling Villages, Shuanglongxia } \\
\text { Natural Scenic Area, "East Hulin People" Site }\end{array}$ & $\begin{array}{l}\text { Red tourism culture, anti-Japanese } \\
\text { culture, Ming and Qing architectural } \\
\text { culture }\end{array}$ \\
\hline $\begin{array}{l}\text { Badaling Town, Yanqing } \\
\text { County }\end{array}$ & $\begin{array}{c}\text { The core area of the Badaling Great Wall Scenic } \\
\text { Area }\end{array}$ & Great Wall Culture, Folk Culture \\
\hline $\begin{array}{l}\text { Panggezhuang Town, } \\
\text { Daxing District }\end{array}$ & $\begin{array}{c}\text { Agricultural sightseeing, picking featuring } \\
\text { watermelon }\end{array}$ & Rural folk culture \\
\hline $\begin{array}{l}\text { Yanqi Town, Huairou } \\
\text { District }\end{array}$ & $\begin{array}{l}\text { Yanqi Lake Tourist Area, No Night Valley } \\
\text { Cultural Performance, Ming Great Wall }\end{array}$ & $\begin{array}{c}\text { Great Wall Culture, Ancient Temple } \\
\text { Culture }\end{array}$ \\
\hline $\begin{array}{c}\text { Shidu Town, Fangshan } \\
\text { District }\end{array}$ & $\begin{array}{c}\text { Shidu Scenic Area, Pingxi Anti-Japanese } \\
\text { Martyrs Cemetery }\end{array}$ & $\begin{array}{l}\text { Film and television culture, ancient } \\
\text { heritage culture }\end{array}$ \\
\hline $\begin{array}{l}\text { Bohai Town, Huairou } \\
\text { District }\end{array}$ & $\begin{array}{l}\text { Chestnut planting, rural folklore tourism and cold } \\
\text { water culture }\end{array}$ & Rural folk culture \\
\hline $\begin{array}{l}\text { Sujiatun Town, Haidian } \\
\text { District }\end{array}$ & Longquan Temple, Single Hammer Drum Club & Historical humanities, temple culture \\
\hline $\begin{array}{c}\text { Jinhaihu Town, Pinggu } \\
\text { District }\end{array}$ & 15 km of Ming Great Wall (General's Gate) & $\begin{array}{l}\text { Great Wall Culture, Folk Culture } \\
\text { (Shadow Play), Religious Culture }\end{array}$ \\
\hline $\begin{array}{l}\text { Tanzhe Temple Town, } \\
\text { Mentougou District }\end{array}$ & $\begin{array}{l}\text { Millennium Ancient Temple Tanzhe Temple, } \\
\text { Plain Ancient Village, North and South Temple }\end{array}$ & Temple culture \\
\hline $\begin{array}{l}\text { Hancunhe Town, } \\
\text { Fangshan District }\end{array}$ & $\begin{array}{c}\text { Upper Mountain National Forest Park, Hancun } \\
\text { River Tourist Village, Isanga Tomb }\end{array}$ & Stone carving culture \\
\hline $\begin{array}{l}\text { Nankou Town, } \\
\text { Changping District }\end{array}$ & Juyongguan Great Wall, Yangtaizi Folk Village & Great Wall Culture \\
\hline $\begin{array}{l}\text { Jiuduhe Town, Huairou } \\
\text { District }\end{array}$ & $\begin{array}{l}\text { The birthplace of the first party branch of } \\
\text { Pinglong Mountain and Pingbei }\end{array}$ & Red tourism culture \\
\hline $\begin{array}{l}\text { Gubeikou Town, Miyun } \\
\text { County }\end{array}$ & $\begin{array}{l}\text { Simatai Great Wall, Gubei Water Town, Meat } \\
\text { Hill Grave }\end{array}$ & $\begin{array}{l}\text { Great Wall Culture, Anti-Japanese } \\
\text { Culture }\end{array}$ \\
\hline $\begin{array}{l}\text { Qianjiadian Town, } \\
\text { Yanqing County }\end{array}$ & $\begin{array}{c}\text { Beijing Yanqing Silicified Wood National } \\
\text { Geological Park, Black Dragon Pool Scenic Area }\end{array}$ & Folk Culture \\
\hline
\end{tabular}

\subsection{Overview of community participation of small towns in Beijing.}

In the process of development, some small tourist towns in Beijing paid attention to the protection of the legitimate rights and interests of community residents, and adopted a series of measures to achieve certain gains. In 2010, Huairou District's Bohai Town, the town's total rural economic income was 520 million yuan; the per capita net income of farmers was 12,320 yuan. In 2010, Jinhai Lake Town of Pinggu District had a tourism income of 71.746 million yuan and a per capita net income of 9647 yuan. The main experience is as follows:

2.2.1 The government drives community residents to implant tourism industry.

Compared with the development of small cities and towns in other provinces and cities, the industry has a single industry and the same phenomenon of resource mines. In the process of development, Beijing tourism towns focus on the localization and differentiation of industries. For example, Panggezhuang Town in Daxing District has made full use of the characteristics of local land to form a characteristic industrial system dominated by melon, pear and meat sheep. The tourism industry has developed rapidly, and on this basis, the five-star hotel and 18-star Longxi Shunjing were built. Cave Golf Course; Tantousi Town of Mentougou District invested 900,000 yuan to drive local residents to develop aquaculture, plantation and folklore tourism, and solve more than 260 jobs; in order to develop the town industry, the enthusiasm of the community residents, Gubeikou, Miyun County The town also issued the first document to encourage farmers to increase their incomes. The Beijing Tourism Town Government has played an important role in the development of tourism. The development of the town is inseparable from the support of the industry. The development of the industry is inseparable from the active participation of the community. 


\subsubsection{Few towns have a guarantee mechanism.}

Beijing is the political and cultural center of China. Its political and cultural atmosphere is strong. Even in the suburbs of Beijing, the work of its government departments is still relatively strong. In the process of developing small towns, a small number of small towns pay attention to the protection of residents' interests and have the interests of coordinating residents. Security mechanism. Zhaitang Town of Mentougou District explored a guarantee mechanism for coordinating residents' rights and interests, and established the “Zhaicheng Tourism” joint-stock cooperative company. The village resources were used as real estate shares and became the controlling party of the company's 55\% shareholding. Private tourism development company-- Kun Investment Group invested in shares and held 45\% of its shares. The 30-50 year cooperation agreement signed by the two parties, each village enjoys a certain amount of interest dividends each year according to the specific circumstances, in addition, it also enjoys the amount of the ticket. It protects the legitimate rights and interests of residents and greatly enhances the enthusiasm of residents to participate in the development of the town.

2.2.3 Some tourist towns offer residents quality and vocational training classes.

With the development of small towns in various parts of the country, the cultural quality and service skills of community residents have become increasingly prominent, and training for community residents is a better solution. The innovative cooperation model of Yanqing County in Beijing, using the joint training of the Qianjiadian Town Social Security Office, the Qianjiadian Vocational Skills Training School and the Shanshui Limin Professional Cooperative, not only improved the quality and professional skills of the farmers in Qianjiadian Town, but also It provides a guarantee for the transfer of employment of rural labor. For the training content of green chemical, public area cleaners and room attendants, community residents are encouraged to participate in tourism services.

\section{Problems in Beijing Community's Participation in the Development of Tourism Town}

At present, Beijing's tourism towns are developing rapidly, bringing rich economic benefits to local governments, community residents and tourism enterprises. However, due to the different types of tourism towns and different stages of development, the scope, content and form of community participation in tourism are also different. There are widespread problems such as the lack of maturity of community participation, the breadth and depth of participation, and the following are summarized as follows:

\subsection{Active participation is less motivated and lacks development vision.}

The development of small towns is inseparable from the active participation of community residents. Although the Beijing town government has explored a good way of community participation in the process of developing the industry, most of the Beijing community residents lack a development perspective and have a weak sense of participation. It is believed that the development of the town is determined by the enterprise and the government, and that it has no idea to pay attention to it. They only care about their immediate interests, look at the short-term economic benefits, and are unwilling to invest too much in their own time, money and land. When the development of the town has gained huge profits, they are not satisfied with their one-time gains, resulting in conflicts of interest arising from the uneven distribution of benefits, which greatly restricts the development of small town tourism.

\subsection{Participation level is shallow; the content of participation is simple.}

The content of Beijing community residents' participation in tourism development mainly includes economic activities such as catering, accommodation and performances. The participation content is simple, the profit channel is single, and the participation level is shallow. Almost rarely participate in in-depth activities related to planning, management and management. When formulating the tourism development plan for small towns, the government and tourism management departments rarely consulted the community residents. Most of the community residents did not understand the current situation of tourism development in small towns and future development ideas. The residents of the town only pay attention to their own interests and have no clear goals for the future development of the town. 


\subsection{Lack of organizational leadership, no safeguard mechanism}

As far as China's community management system is concerned, the Community Residents Committee is responsible for managing all aspects of the community. As a community resident committee of the grassroots "autonomous" organization, this should be responsible for the community residents, but at present the residents committee of small towns in Beijing reflects the will of the government and realizes a top-down management. True community participation should be the broad participation of residents from the bottom up. To achieve this kind of participation requires grassroots leaders and organizers who can represent the interests of the community and have dedication, fairness and integrity. Due to the limited capacity of the current community residents in Beijing, this kind of inspiring and cohesive leadership elite is lacking. At the same time, small towns in tourism have not formed a relatively complete community management system and operational mechanism. Therefore, community residents who lack protection mechanisms can only participate in the construction of small towns with passive, small-scale and symbolic participation.

\section{The Path of Community Participation in Tourism Town Development}

Community participation in tourism Small town construction and management vary according to specific community development conditions, development stage, community situation and community residents' conditions. It is the basic principle of community participation in tourism development to develop a participation plan that suits different community conditions. As for the common characteristics of Beijing community residents participating in the development of small towns, the following strategies should be adopted.

\subsection{Establish a legal and institutional guarantee system}

The development and construction of small tourist towns in Beijing are basically government-led, so ensuring the participation of communities in the development of small towns is inseparable from the important role of the government. Through a series of measures, the government can ensure the substantial participation of community residents in the development of small towns: for example, by providing necessary financial support for community residents, formulating policies and measures such as tax incentives and employment priorities to improve the participation of community residents; Establish a standardized decision-making participation mechanism to enable community residents to participate in the finalization of the benefits distribution plan to ensure that the interests of the community are not violated; to ensure that community residents fully understand by inviting community residents to participate and contribute to the town's tourism planning and construction. The future development plan of tourism towns.

\subsection{Ensuring the substantial participation of community residents}

The development and construction of small tourist towns in Beijing are basically government-led, so ensuring the participation of communities in the development of small towns is inseparable from the important role of the government. Through a series of measures, the government can ensure the substantial participation of community residents in the development of small towns: for example, by providing necessary financial support for community residents, formulating policies and measures such as tax incentives and employment priorities to improve the participation of community residents; Establish a standardized decision-making participation mechanism to enable community residents to participate in the finalization of the benefits distribution plan to ensure that the interests of the community are not violated; to ensure that community residents fully understand by inviting community residents to participate and contribute to the town's tourism planning and construction. The future development plan of tourism towns.

\subsection{Play the role of bridges between NGOs}

Non-governmental organizations are not the interests of tourism small town development. Their grassroots and public welfare characteristics make them maintain natural and close contact with community residents, and can objectively integrate the opinions of government and community residents. Therefore, in the process of the development of tourism towns in Beijing, we must pay attention to the role of NGOs as bridges and bridges, and establish community-based organizations as the core of participation carriers through the establishment of community owners' committees and volunteer associations. Play the role of its bridge. 


\section{Conclusion}

The community is an important resource and support for the development of small towns. The residents of the community are not only the consumers in the tourism towns, but also the producers of tourism products and the supporters of service supply. The development of small towns is inseparable from community participation, but realizing the community participation in the development of tourism towns is inseparable from the support of government organizations and the coordination of elements of non-governmental organizations. The coordinated development of the various small cities and towns, the government, enterprises and community residents work together to truly realize community participation and promote the healthy and sustainable development of tourism in small towns.

\section{References}

[1]. Bowei Zeng. Research on the Development of Small Town for Tour in China[D]. Doctoral Thesis of Minzu University of China, 2010, (3): 1-79. (In Chinese)

[2]. State Council. Several opinions of the State Council on promoting the reform and development of tourism [Z]. The Central People's Government of the People's Republic of China, 2014-08-21. (In Chinese)

[3]. Sherlock K. The Role of Community in Tourism Studies[J]. International Journal of Contemporary Hospitality Management,1999,11( 2 /3) : 126 -127.

[4]. Zhengchao Xia. Research on the Dynamic Mechanism of Tourism Town Development[J]. Regional Research and Development, 2015,(5): 91-92. (In Chinese)

[5]. Zhaorong Meng, Shumei Xu. Strategies for Community Residents to Participate in the Development of Small Town for Tour[J]. Economic Research, 2016,(2): 134-137. (In Chinese)

[6]. Bifan Cai, Zhuomin Tao. A Comparative Study of Participatory Models of Rural Tourism Community —-Taking Three Villages in Zhejiang Province as an Example[J]. Business research, 2013,(10): 191-196. (In Chinese)

[7]. Mingming Su. Heritage Tourism and Community Participation-Taking the Mutianyu Great Wall in Beijing as an Example[J]. Tourism Journal, 2012,(7):24-25. (In Chinese) 